\author{
Zoriana Kovalchuk, \\ Doctor of Psychology, \\ Deputy Dean for Academic Affairs at Faculty No. 7, \\ Lviv State University of Internal Affairs, \\ 1, Kryvonosa Str., Lviv, Ukraine
}

\title{
PSYCHOLOGICAL ANALYSIS OF INTRAPERSONAL CONFLICT IN SECONDARY SCHOOL STUDENTS
}

The article deals with the phenomenon of interpersonal conflict in secondary school students. The survey involved 53 respondents including 30 girls and 23 boys aged from 12 to 14 using the following methods: E. Fantalova's ValueAttainability Ratio in Various Life Spheres Scale; Lazarus' Coping Test; Butler and Haigh's Correlation between the Actual and Ideal Self Test and Eysenck Personality Questionnaire. According to the research results, intrapersonal conflict was detected in 35 children (66\%). One of the most effective psychological technologies for intrapersonal conflict elimination in children and adolescents is socio-psychological training whose positive effect is ensured by the basic principles of working in the group. It should involve exercises for the formation of an adequate self-esteem; for the development of empathy and tolerance. Also, the training sessions should include exercises to eliminate anxiety, reduce aggression and to control it; to form the ability to make decisions independently, considering their consequences (both positive and negative) and bear responsibility for them, etc.

Keywords: intrapersonal conflict, adolescent, coping strategies, boundary condition, self-concept.

\section{Introduction}

High unemployment rate, social exclusion and degradation of moral values have become commonplace in the modern world. Consequently, people have turned cruel and selfish, and such feelings as love, care, support and trust seem to be forgotten. In this situation children are the first to suffer as their needs for such essential emotions are not fully satisfied, which gives rise to intrapersonal conflict.

The issue of intrapersonal conflict is still not completely understood but one could argue that it is one of the most complex and complicated phenomena. Quite often adolescents' behavior goes beyond the norm; they become aggressive, irritable, and anxious. Most parents and teachers tend to blame it on teenage crises still hoping that over time behavior of their children will improve again. But this is not always the case.

Internal conflict is treated in works of renowned foreign psychologists such as S. Freud, A. Adler, K. Horney, K. Lewin, C. Rogers, V. Frankl, R. Assagioli, C. Jung, E. Erikson, E. Fromm, L. Festinger, R. May, F. Perls, A. Maslow. Some Ukrainian and Russian scholars have also taken an interest in the issue of intrapersonal conflict, for example A. Luria, V. Myasishchev, I. Kon, A. Zakharov, V. Merlin, A. Leontyev, V. Stolin, F. Vasilyuk, O. Donchenko, T. Tytarenko, S. Rubinstein, L. Vygotsky, N. Grishina. Although the representatives of various directions interpret the concept under analysis differently, they do agree that internal conflict is a negative experience caused by the struggle of various internal structures of a personality.

The scientific study of the concept began in the late $19^{\text {th }}$ century. However, so far the scholars have failed to provide a common understanding of the term "internal conflict". Sigmund Freud, the founder of psychoanalysis, was the first among foreign scholars to have started looking into the issue. He saw the conflict as a permanent feature of the human psyche that forms at the early stages of the child-parent relationship. According to Freud, the essence of intrapersonal conflict lies in constant tension and overcoming of contradictions between biological impulses and desires, on the one hand, and socio-cultural norms, on the other, i.e. between the subconscious and conscious minds [13].

Within the psychoanalytic approach the issue of intrapersonal conflict was also studied by Alfred Adler, Karen Horney, Carl Jung, Erich Fromm. For instance, A. Adler believed that the source of internal conflict is an inferiority complex of personality, which stands in opposition to the pursuit of perfection [1].

K. Lewin, a representative of Gestalt psychology, identified internal conflict as a situation in which an individual is simultaneously influenced by two oppositely directed forces of approximately equal value. K. Lewin identified the following three types of intrapersonal conflict: conflict between two positive valences; conflict between approximately equal negative valences; conflict of positive and negative valences [5].

The founder of the cognitive dissonance concept $\mathrm{L}$. Festinger viewed internal conflict as a state of discomfort, which is based on a simultaneous presence in an individual's consciousness of several controversial cognitions with respect to a particular object. He believed that an individual always seeks to reconcile his/her internal system of beliefs and values and when contradictions arise he/she feels discomfort and frustration [11].

Carl Rogers, one of the founders of humanistic psychology, believes that the cause of internal conflict is the 
difference between an individual's "real self" and "ideal self" [10].

According to another representative of humanistic psychology Abraham Maslow personality consists of hierarchically organized needs, the ultimate being the need of self-actualization. Failure in self-actualization or partial realization of skills and talents are the basis of internal conflict [8].

According to Austrian psychologist Viktor Frankl, the main idea of human existence is search for and comprehension of sense of purpose. However, not everyone can find it and this deficiency creates an existential vacuum. V. Frankl believed that it is this feeling of emptiness which causes intrapersonal conflict [12].

R. Assagioli, the founder of psychosynthesis, tried to systematize the knowledge about internal conflict. He believed that since a man strives for inner harmony, the basis of internal conflict is the presence of powerful contradictions inside his/her personality that weaken the overall integrity of the self-concept [2].

So, in foreign psychology intrapersonal conflict was studied by the representatives of numerous psychological theories and concepts and viewed through the prism of understanding of personality.

The issue of intrapersonal conflict has been thoroughly studied in Ukrainian and Russian psychological discourse. Specifically, A. Luria regarded internal conflict as a situation where human behavior incorporates two strong oppositely directed trends. On the basis of experimental research, he singled out the following varieties of conflict: 1) conflict caused by a strong stimulus acting on the body so the problem is too severe and leads to a conflict between the response and its satisfaction; 2) conflict of countervailing behavioral trends that arise on the basis of personal motives or via external prohibitions that prevent occurrence of the trends; 3 ) conflict of inner attitudes, their violation, discontinuation of familiar and a sudden emergence of new conditions [7].

A. Leontyev considered the issue in the context of the activity approach. He believed that intrapersonal conflict is caused by the very nature of internal structures of personality. Despite having a predominant motive of behavior one cannot follow it all the time. A controversial interaction of different motives creates an internal conflict [6]. S. Rubinstein believed the source and main feature of intrapersonal conflict is unsubjectiveness of personality and its low volitional regulation. As a result there is no active life position; a person rejects social experience or establishment of social ties.

V. Myasishchev treated intrapersonal conflict as a clash of conflicting relations of a person who cannot find a rational way out. Internal conflict is a mismatch between the needs and their satisfaction and can be both a source of personal development and a destructive factor [9]. F. Vasilyuk holds a similar view of internal conflict. He believes it is a critical situation where it is impossible to select one of two things, where psychological future is at risk [3].
Modern Ukrainian scholars O. Donchenko and T. Tytarenko believe internal conflict arises from internal contradictions that create a dichotomy in human consciousness and trigger tense and problematic behavior. According to them, for internal conflict to occur there should be inconsistency between three aspects of personality: operational, motivational and conceptual. The inconsistency causes a reaction aimed at overcoming the condition which results in reorganization of life [4].

Thus, the problem of intrapersonal conflict is explained differently by different scholars. However, the common denominator is the idea of negative experiences, caused by the collision of two equal or opposite in character motives needed for making a decision.

Determinants of internal conflict can be internal or external. Internal causes include a contradiction between the need and a social norm when a person wants something but it does not meet social norms, or a way to meet this need goes beyond the social norms (low wages provoke unlawful earnings); conflict of motives, interests and needs (having a rest vs. preparing for classes); clashing social roles (as a father a man should protect his child in all situations, but as a legal agent he must bring his child to account for an offense); conflict of social values and norms as a person interacts with various social groups having their own values and norms which may not match those of the person. However, for an intrapersonal conflict to arise these contradictions should have a deep personal meaning, otherwise a person will not regard them with much importance.

The external causes of internal conflict are associated with individual's social position. But internal conflicts which arise only due to internal or external factors do not exist. The reasons for their emergence are always mixed, internal factors are determined by external conditions and vice versa.

By its nature intrapersonal conflict can be both constructive and destructive. A constructive internal conflict is a source of self-improvement and self-assertion of an individual and promotes personal development. A destructive internal conflict has a negative impact on the internal structure of personality, interaction with other people and can lead to the emergence of stress, frustration and neurosis.

This contradiction in the internal structure of a personality is usually not recognized by an adult, let alone a child, which explains the difficulty of its detection. However, using psychological techniques such as individual diagnostic interviews, open or covert observation, autobiographical interviews, questionnaires and tests researchers have an opportunity to detect internal conflict in adolescents.

The paper aims to reveal the nature of intrapersonal conflict, as well as to detect the interpersonal conflict in adolescents.

\section{Research methods}

The survey was conducted in a secondary school and involved 53 pupils including 30 girls and 23 boys aged 
from 12 to 14 .

In order to study the internal conflict in the respondents effectively we used the tests based on the following methods: E. Fantalova's Value-Attainability Ratio in Various Life Spheres Scale; Lazarus' Coping Test; Butler and Haigh's Correlation between the Actual and Ideal Self Test and Eysenck Personality Questionnaire.

\section{Discussion}

A summative experiment involving secondary school students has revealed the following parameters. According to E. Fantalova's Value-Attainability Ratio in Various Life Spheres Scale it has been found that 35 adolescents under analysis (in a sample of 53), including 21 girls and 14 boys, display intrapersonal conflict. Mostly internal conflict arose from a adolescent's inability to satisfy his/her need for a happy family life (score 11) - 14 respondents, lack of love and caring (score 5) - 8 respondents.

Also, 12 respondents had internal conflict due to the lack of hobby (score 3), 7 respondents - due to the lack of freedom or independence in their actions (score 10), 4 respondents - because of a limited access to knowledge and cultural development (score 9), 4 respondents - as a result of certain health problems (score 2), 2 respondents - because of insufficiently active lifestyle (score 1), 1 respondent - due to the inability to take part in creative activities (score 12). Intrapersonal conflict could also arise because of self-doubt (score 8 ) -1 adolescent, the lack of loyal friends (score 7) -2 adolescents, due to dissatisfaction with their financial situation (score 6) -5 adolescents.

Also, 39 adolescents, including 22 girls and 17 boys, demonstrated an internal vacuum, i.e. a condition that creates discomfort and feeling of insignificance. In 7 respondents ( 3 girls and 4 boys) indicators of disintegration in the motivational sphere of a personality were above average.

Lazarus' Coping Test has shown what coping strategies respondents used to overcome difficulties in different areas of mental activity. Thus, the adaptive type of coping included confrontational coping - 10 adolescents; distancing - 15 adolescents; self-control -5 adolescents; searching for social support -5 adolescents; taking responsibility -18 adolescents; escape/avoidance -6 adolescents; planning how to solve a problem -6 adolescents; positive reevaluation -2 adolescents.

Borderline adaptability was found in relation to the following coping skills: confrontational coping - 40 children; distancing - 32 respondents; self-control - 33 respondents; searching for social support - 33 respondents; taking responsibility - 35 respondents; escape/avoidance -32 respondents; planning how to solve a problem - 28 respondents; positive reevaluation -21 respondents.

High stress coping capacity, which may indicate severe maladjustment, was represented as follows: confrontational coping -3 adolescents; distancing -6 adolescents; self-control - 15 adolescents; searching for social support - 15 adolescents; taking responsibility - no high stress detected; escape/avoidance - 15 adolescents; planning how to solve a problem - 19 adolescents; positive reevaluation -30 adolescents.

However, most respondents demonstrated not only low to medium parameters. The distribution of low, medium and high parameters appeared to be equal.

By testing the differences between the actual and ideal self (Butler and Haigh), we could figure out how different the respondents' perception of what they really are and of what they would like to be was. Having processed the data, we have obtained the following results: 25 respondents out of 53 were happy, their level of difference between the actual and ideal self was low; in 14 adolescents the difference was tangible but not significant. Normally, this indicates that the respondents are aware of their weaknesses, but also know how to fix them and are not bothered by them too much. They have a clear vision of their self-image.

Also, 8 respondents displayed medium difference, 6 respondents - high difference between the actual and ideal self. This means that their idea of what they are at the moment and of what they would like to be is very different. It often indicates low self-esteem and "selfconcept" immaturity. The parameters of the boys' and girls' self-image were also different. The high level of difference between the ideal and the real self has been revealed in 5 boys and only 1 girl, the medium one - in 5 girls and 3 boys; the insignificant level - in 11 girls and 5 boys, and low - in 14 girls and 11 boys. The reason for this is the age of the respondents: male adolescents are often insecure and have low self-esteem.

We used Eysenck Personality Questionnaire to determine the level of some mental states such as anxiety, frustration, aggression and rigidity (see Table 1). 25 respondents ( 11 boys and 14 girls) demonstrated the low level of anxiety or its absence; 24 ( 8 boys and 16 girls) the medium allowable level of anxiety; and 4 boys - the high level of anxiety.

21 respondents (10 boys and 11 girls) showed no frustration, strong resistance to failure and no fear of difficulties; 30 (12 boys and 18 girls ) - the medium level of frustration; and 2 ( 1 boy and 1 girl) - the high level of frustration that may indicate low self-esteem, avoidance of difficulties and fear of failure.

24 students (10 boys and 14 girls) had the low level of aggressiveness indicating their calmness and restraint; 28 respondents (13 boys and 15 girls) had the medium level of aggressiveness; and 1 student had the high level of aggressiveness and incontinence, and thus potential communication barriers.

In 9 students ( 4 boys and 5 girls) rigidity was not found, they could easily switch from one stimulus or process to another; 43 children (18 boys and 25 girls) displayed medium rigidity; and 1 pupil demonstrated high rigidity, inflexibility of behavior, beliefs and opinions even if they were proven wrong in real life situations. 
Table 1.

Manifestations of mental states

\begin{tabular}{|l|c|c|c|c|}
\hline \multicolumn{1}{|c|}{ Manifestation } & Anxiety & Frustration & Aggressive- & Rigidity \\
\hline Low level & 25 children & 21 children & 24 children & 9 children \\
\hline Medium level & 24 children & 30 children & 28 children & 43 children \\
\hline High level & 4 children & 2 children & 1 child & 1 child \\
\hline
\end{tabular}

\section{Conclusions}

Having analyzed the results of our study, we have found that 5 out of 53 adolescents had standard parameters for all 4 methods; 15 respondents - for 3 methods; 22 respondents - for only 2 methods; and 11 respondents for only one (out of 4) method without exceeding the norm. None of them had high parameters for all 4 or at least 3 methods. However, intrapersonal conflict was detected in 35 respondents $(66 \%)$. Also, we studied the behaviour strategies of adolescents in difficult life situations, and their level of difference between the real and ideal self, that is, how far their representation of what they are now really is and how they want to be. And with the help of Eysenck's technique, we established the degree of expression in subjects of such mental states as anxiety, frustration, aggression and rigidity.

The overcoming of intrapersonal conflict is not an easy task, since first it is necessary to diagnose this state and only then to select the methods and technologies of its eliminating among a great number of them having different effects.

In our opinion, the most effective psychological technology for intrapersonal conflict elimination in adolescents is socio-psychological training whose positive

\section{REFERENCES}

1. Adler, A. (1994). Ponyat prirodu cheloveka [Understanding Human Nature]. Saint Petersburg: Gumanitarnoye agentstvo "Akademicheskiy proyekt" [in Russian].

2. Assagioli, R. (1994). Psikhosintez: teoriya i praktika [Psychosynthesis: A Manual of Principles and Techniques]. Moscow: Refl-book [in Russian].

3. Vasilyuk, F. Ye. (1984). Psikhologiya perezhivaniya (analiz preodoleniya kriticheskikh situatsiy) [Psychology of Anxiety (Overcoming Critical Situations)]. Moscow: MGU [in Russian].

4. Donchenko, Ye. A., \& Tytarenko, T. M. (1989). Lichnost. Konflikt. Garmoniya [Personality. Conflict. Harmony]. Kyiv: Politizdat Ukrainy [in Russian].

5. Levin, K. (1982). Tipy konfliktov [Types of Conflicts]. Psikhologiya lichnosti. Teksty - Psychology of Personality. Texts. Moscow: MGU [in Russian].

6. Leontyev, A. M. (2004). Diialnist, svidomist, osobystist [Activity, Consciousness, Personality]. Psykholohiia osobystosti. Teksty - Psychology of Personality. Texts. Yu. B. Gippenreyter, A. A. Puzireva (Ed.). Moscow: MGU [in Ukrainian].

7. Luria, A. R. (1930). Eksperimentalnyye konflikty u cheloveka [Experimental Conflicts of an Individual]. effect is ensured by the basic principles of working in the group. The training program will be compiled on the basis of the findings of the summative experiment. In particular, it should involve exercises for the formation of an adequate self-esteem because the low one can cause the emergence of internal conflict; exercises for the development of empathy and tolerance, as well as those aimed at the development of self-disclosure and self-awareness, motives and values that should help to understand the reasons that have provoked the internal conflict and the ways to overcome it. Also, the training sessions should include exercises to eliminate anxiety, reduce aggression (which are the consequences of the intrapersonal conflict) and to control it; exercises to form the ability to make decisions independently, considering their consequences (both positive and negative) and bear responsibility for them; and, of course, the exercises for the constructive solution of interpersonal conflicts, which may be the cause of the emergence of the intrapersonal conflict.

It is planned to perform the research aimed at the development of the socio-psychological training for intrapersonal conflict elimination and conduct reassessment of the data.

Problemy sovremennoy psikhologii. Uchenyye zapiski Moskovskogo gos. in-ta eksperimental'noy psikhologii Problems of Modern Psychology. Proceedings of Moscow State Experimental Psychology Institute. (pp. 98-137). Moscow: Leningrad [in Russian].

8. Maslow, A. (1999). Motivatsiya i lichnost [Motivation and Personality]. Saint Petersburg: Yevraziya [in Russian].

9. Myasishchev, V. N. (1960). Lichnost i nevrozy [Personality and Neuroses]. Leningrad: Izd-vo LGU [in Russian].

10. Rogers, C. (1994). Vzglyad na psikhoterapiyu. Stanovleniya cheloveka [On Becoming a Person: A Therapist's View of Psychotherapy]. Moscow: Progress "Univers" [in Russian].

11. Festinger, L. (2000). Teoriya kognitivnogo dissonansa [A Theory of Cognitive Dissonance]. Saint Petersburg: Rech [in Russian].

12. Frankl, V. (1990). Chelovek v poiskakh smysla [Man's Search for Meaning]. Moscow: Progress [in Russian].

13. Freud, S. (2015). Vvedeniye v psikhoanaliz. Lektsii [A General Introduction to Psychoanalysis. Introductory Lectures]. Moscow: Azbuka-Attikus [in Russian]. 


\section{ЛІТЕРАТУРА}

1.Адлер А. Понять природу человека / А. Адлер. - СПб.: Гуманитарное агентство «Академический проект», 1997. - 256 с.

2.Ассаджиоли Р. Психосинтез: теория и практика / Р. Ассаджиоли. - M.: Refl-book, 1994. - 314 c.

3.Василюк Ф. Е. Психология переживания (анализ преодоления критических ситуаций) / Ф. Е. Василюк. - М.: МГУ, 1984. -200 с

4. Донченко Е. А. личность. Конфликт. Гармония. / Е. А. Донченко, Т.М. Титаренко. - К.: Политиздат Украины, 1989. - 175 с.

5. Левин К. Типы конфликтов / К. Левин // Психология личности. Тексты. - М.: МГУ, 1982.

6. Леонтьєв А. М. Діяльність, свідомість, особистість / А. М. Лєонтьєв // Психологія особистості. Тексти / За ред. Ю. Б. Гіппенрейтер, А. А. Пузирея. - М.: Изд-во МГУ, 2004.

7. Лурия А. Р. Экспериментальные конфликты у человека / А. Р. Лурия // Проблемы современной психологии. Ученые записки Московского гос. ин-та экспериментальной психологии. - М. - Л., 1930. - С. 98-137.

8. Маслоу А. Мотивация и личность / А. Маслоу. - СПб.: Евразия, 1999. - 478 с.

9. Мясищев В. Н. Личность и неврозы / В. Н. Мясищев. - Л.: Изд-во ЛГУ, 1960. - 425 с.

10. Роджерс К. Взгляд на психотерапию. Становления человека / К. Роджерс. - М.: Прогресс «Універс». 1994. - 480 с

11. Фестингер Л. Теория когнитивного диссонанса / Л. Фестингер. - СПб.: Речь, 2000. - 318 с.

12. Франкл В. Человек в поисках смысла / В. Франкл. - М.: Прогресс, 1990. - 395 с.

13. Фрейд 3. Введение в психоанализ. Лекции / 3. Фрейд. - М.: Азбука-Аттикус, 2015. - 480 с.

Зоряна Ярославівна Ковальчук, доктор психологічних наук, доцент, заступник декана факультету №7 з навчально-методичної роботи, Львівський державний університет внутрішніх справ, вул. Кривоноса, 1, м. Львів, Украӥна

\section{ПСИХОЛОГІЧНИЙ АНАЛІЗ ВНУТРІШНЬООСОБИСТІСНОГО КОНФЛІКТУ В УЧНІВ-ПІДЛТКІВ}

У статті автор розкриває сутність внутрішньоособистісного конфлікту, аналізує зарубіжну та вітчизняну літературу з цієї проблеми. Зокрема, подано бачення проблеми науковців психоаналітичного напрямку, гештальт-психології, через концепцію когнітивного дисонансу, представників гуманістичної, екзистенційної психології, концепції психосинтезу, діяльнісного підходу та інших. Було проведено емпіричне дослідження, у якому взяли участь 53 школяра загальноосвітньої школи віком від 12 до 14 років. Було використано комплекс із 4 методик: методика «Рівень співвідношення «цінності» і «доступності» в різних життєвих сферах» (О. Б. Фанталової), копінг-тест Лазаруса, тест відмінностей між ідеальним і реальним Я (Батлера-Хайга) і тест Айзенка «Самооцінка психічних станів». За результатами дослідження у 66\% підлітків загальноосвітньої середньої школи було виявлено внутрішньоособистісний конфлікт. Також показано, що лише у 5 із 53 підлітків показники за всіма методиками знаходяться в межах норми; у 15 дітей - показники в нормі за 3 методиками; у 22 дітей - лише за 2; і в 11 дітей лише за однією методикою показники не перевищують норми. Дітей, у яких показники за всіма 4, чи хоча 63 методиками, були б високі - не виявлено. Обгрунтовано потребу в розробці соціальнопсихологічного тренінгу як одного $з$ методів нейтралізації внутрішньоособистісного конфлікту та проведення повторного зрізу даних.

Ключові слова: внутрішньоособистісний конфлікт, підліток, копінг-стратегії, пограничний стан, Яконцепція.

Submitted on February, 23, 2017 